\title{
Inclusive education in Islamic kindergarten, why not?
}

\author{
M. Agung Hidayatulloh \\ IAIN Salatiga \\ agung24hidayat@gmail.com
}

DOI: $10.18326 /$ mudarrisa.v9i2.145-162

\begin{abstract}
This work shows the implementation of inclusive education in Islamic Kindergarten Taruna al-Qur'an (IKTQ), the assessment of child development in inclusive class, and supporting and restriction of the implementation of inclusive education in IKTQ. This qualitative descriptive research used observation, interview, and documentation as the technique of collecting data. The results are only the ABK with less in terms of social skills that were included in the non-ABK class. IKTQ pointed the special guides that monitored the development of ABK. The development of the child was assessed through observations and notes. These notes were documented as reports of child development communicated to the parents. The assessment did not touch the ABKs who joined in learning with other children. The development of ABK was assessed when they were in a special place of ABK therapy. The factors supported the implementation of inclusive education in IKTQ were: (1) the communication between teachers and ABK guides, (2) a good relationship through weekly meeting for all teachers, and (3) the communication between IKTQ and parents either verbally or through a liaison document. Regarding the restriction, the teachers explicitly express that there were no obstacles in the implementation of inclusive education in IKTQ.
\end{abstract}

Keywords: inclusive, $A B K$, Islamic kindergarten 


\section{INTRODUCTION}

It is known that Early Childhood Education (ECE) plays an important role and very decisive for the child development. It can also be said that early education can be the foundation of the child's personality. Children who get coaching from an early age are more able to be independent and optimize their potential (Rahman, 2002).

It is mentioned in the Indonesian Laws Number 20 Year 2003 that every citizen has the same right to obtain quality education. Therefore, the right to obtain the same education must be enjoyed by all citizens without exception, including children with special needs (ABK). Even so, the educational institution must accept the children of all classes regardless of tribe, religion, social group, and economic ability. To cover ABK, one of the educational programs worth appointing is inclusive education. Related to this case, Smith, as quoted by Sumiyati, describes inclusion as a more positive education for bringing together children who have obstacles in ways that are comprehensive in educational life (Sumiyati, 2011).

Inclusion, in Indonesia, provides the opportunity for $\mathrm{ABK}$ and other children who have not been able to receive education because of the various things that prevent them from getting a chance to go to school. Implementation of inclusive education requires the school to make adjustments in terms of curriculum, educational facilities and infrastructure, as well as learning systems adjusted to the needs of individual learners. 


\section{Mudarrisa: Jurnal Kajian Pendidikan Islam, Vol. 9, No. 2, 2017}

As an implication of curriculum existence, learning becomes very important in inclusive education. To be able to provide education that can be accounted for, every educational institution should be able to nicely package the learning system. Interrelated to this case, there is an Islamic Kindergarten that since 2005 has tried to organize inclusive education for early $\mathrm{ABK}$ in Yogyakarta. This Islamic Kindergarten is Taruna al-Qur'an (IKTQ). In its learning, $A B K$ is included with other children (they are then called non-ABK). Further, the learning process of $A B K$ is not necessarily separated from those who are non-ABK. This then becomes something unique to observe, namely about inclusive learning in IKTQ involving non- $A B K$ and $A B K$.

IKTQ stood on July 1, 1998 under the Foundation of Taruna alQur'an. IKTQ, in 2011, had 14 teachers. All of them were woman and two of them were guides of ABK. The students were 185 children. Two of them were ABK that consist of a boy (Fulan) and a girl (Fulanah). The guides suggested that Fulanah was generally able to socialize in teaching and learning activities. However, she was disturbed in motor development so that an intensive mentoring was necessary for her. Meanwhile, Fulan, is generally able to socialize in teaching and learning activities. Nevertheless, he was sometimes very difficult to be directed to follow the process of learning in the classroom, so that an intensive assistance for him is an undeniable requirement (NN, 2011).

Based on the explanation above, this work was focused on these two cases: (1) How does inclusive learning process of Islamic Kindergarten 
Taruna al-Qur'an involving non-ABK and ABK? (2) How is the process of assessing the development of learners in the Islamic Kindergarten Taruna al-Qur'an involving non- $\mathrm{ABK}$ and $\mathrm{ABK}$ ? (3) What are the supporting factors and obstacles in the inclusive learning process in Islamic Kindergarten Taruna al-Qur'an involving non-ABK and ABK?

\section{METHODS}

This work used a qualitative descriptive method. It is known that descriptive research is a type of research that provides an overview or description of a similar circumstances which is possibly without any treatment to the object studied (Kountur, 2005). Furthermore, qualitative is a method of research in which the results are founded not form statistic data or other shapes of quantification (Strauss \& Corbin, 2003).

From that enlightenment, this research was directed to describe comprehensively, holistically, integratively, and deeply about a phenomenon, event, current occurrence which was directly related to the implementation of inclusive education in IKTQ. IKTQ itself is located in Sariharjo Ngaglik Sleman Yogyakarta. Since this research is a field research, the data source was in the form of data covering actors, activities, and places. The research was held in the end of December 2011.

In determining the respondents, as appointed by Arikunto, the researcher saw a number of people in accordance with the objectives and the relevance to the formulation of the problems and of course the purposes of the study (Arikunto, 1991). The data of this study was 
classified into primary data and secondary data. The first one is data obtained directly from the object being studied, while the second one is data that is not disclosed directly by the concerned.

The techniques of collecting data used were observation, interview, and documentation. The first technique was used to observe the activities of non- $\mathrm{ABK}$ and $\mathrm{ABK}$ in both classes, indoor and outdoor. The second technique was used to make a face-to-face talk with teachers, co-teachers, principle, and the guides of ABK. Meanwhile, documentation is a source of information in the form of writing or documents in which the text or document can be used as a source of reference in the research process (Suakardi, 2002). Form this technique, RKH (daily lesson plan) and RKM (weekly lesson plan) were the collected documents that related to the topic studied.

\section{DISCUSSION}

The concept of learning, according to Corey and restated by Sagala, is a process in which a person's environment is deliberately managed to enable him to participate in certain behaviors under specific conditions or generate responses to a particular situation (Sagala, 2010). From another source, the term "instruction" means the effort to make a person or group of people learn through various efforts and a variety of strategies, methods, and approach toward the achievement of objectives that have been planned (Zayadi \& Majid, 2005). 
Meanwhile, inclusion or inclusive education is not another name for "special needs education". Inclusive education uses a different approach to identifying and trying to solve the difficulties that arise in school. The concept of inclusive education has more in common with the concept that underlies the "education for all" movement and "school quality improvement". Inclusive education is a shift away from anxiety about a particular group into a focused effort to overcome barriers to learning and participation (Stubbs, 2002).

Education as a right for all children has been listed in various international instruments starting from the 1948 Universal Declaration. Subsequent instruments show that certain groups, including children with disabilities, are particularly vulnerable to marginalization. The right to education "within" the public education system and not to be discriminated against has been highlighted in more detailed instruments such as the Jomtien Declaration and the UN Convention on the Rights of the Child. However, the right to education does not automatically imply inclusion. The most obvious right to inclusive education has been stated in the Salamanca Statement and Framework for Action which emphasizes that schools need change and adjustment (Stubbs, 2002).

In relation to educational practices, inclusive education is seen to have successfully improved the quality of schools and special needs education. Improving school quality is an excellent preparation for inclusive education, but it is often not good enough to actually include the most marginalized groups of children. Special needs education has 


\section{Mudarrisa: Jurnal Kajian Pendidikan Islam, Vol. 9, No. 2, 2017}

contributed very practical skills and some who have turned the corner into inclusive education can be very strong supporters but can also be an impediment since their basic philosophy does not provide an appropriate basis for the sustainability of inclusive education (Stubbs, 2002).

The main issue in inclusive education itself is that inclusive education is based on human rights and social models. Here the system must be adjusted to the child, not the child who adjusts to the system. Inclusive education can be viewed as a movement that upholds major values, beliefs and principles relating to children, education, diversity and discrimination, the processes of participation and available resources. Many of these are challenges to the status quo, but it is important that society and overall development want to be inclusive and benefit all citizens (Stubbs, 2002).

Many people think that to pour the idea of inclusive education into practice is merely introducing specific techniques and methods for each child to learn. With the method alone will not result in an inclusive education program that is appropriate and sustainable. Three "main ingredients" are proposed to produce dynamic and powerful organisms that can adapt, grow and survive in various contexts. These materials will largely determine the success and sustainability of inclusive education.

The three main ingredients are (1) strong framework $\rightarrow$ frame (values, beliefs, principles and indicators of success); (2) implementation in the context and local culture $\rightarrow$ meat (taking into account the practical situation, the use of available resources and factors; local cultural factors), 
(3) ongoing participation and critical self-reflection $\rightarrow$ blood of life (who should be involved, how, what, and when). Together, these three main ingredients can produce a flexible, robust, sustainable, on-site and sustainable education system that includes all children (Stubbs, 2002).

In recent years, Indonesia is a country which is diligent to pep up the inclusive education. This spirit then grows and spreads to the regions. In Yogyakarta, there is Islamic Kindergarten Taruna al-Qur'an (IKTQ) which in recent years has been trying to become one of the early childhood education units that inclusive for all children. In everyday life, learning is not only followed by standard children (non-ABK), but also followed by children with special needs (ABK).

IKTQ deliberately accepts students such as ABK because, admittedly or not, everyone is entitled to education. The implication is that $\mathrm{ABK}$ is accepted to be a learner in that kindergarten. In the academic year 2011/2012, ABK participated in learning was actually 12 children. However, not all of them were immediately joined in or mixed with nonABK. Based on the IKTQ policy, only the ABK is considered less in terms of social skills that are included in the (non-ABK) class. The condition can be observed from the child's daily activities. Related to this, IKTQ provides special teachers who oversee the development of ABK. After ABK is considered really need socialization, they will be included in the learning in the classroom of non-ABK.

Note that the Taruna al-Qur'an has a special place that is destined for $A B K$. In that place, guides give training or therapy related to the 
particularity of ABK. For example, hyperactive children are given certain exercises aimed at slightly reducing the speed and intensity of their activities. From the results of the policy, IKTQ finally determined two ABKs who need to follow the learning process with non-ABK. This is important because it is a form of training and as a provision before $\mathrm{ABK}$ wrestle with a real life around it in the future.

Regarding the daily routine, IKTQ has two kinds of programs, namely regular program and diniyah program. These two programs are as the implication of the application of two integrated curriculums, namely the general early childhood curriculum which is compiled by the National Education Department and curriculum based on pesantren (Islamic school). The former is widely known, while the second refers to a curriculum whose contents are the prominent points of the religiosity. Therefore, the impression of Islam and the power of religiosity will be evident in the process of daily learning (Emiyati, 2011).

The two kinds of programs above have been scheduled well and can be seen from the following tables.

Table 1 Regular curriculum program

\begin{tabular}{ll}
\hline Time & Activities \\
\hline 07.30-08.00 & $\begin{array}{l}\text { Line up } \\
\text { Opening } \\
\text { Memorizing short verses of al-Qur'an }\end{array}$ \\
\hline 08.00-09.00 & $\begin{array}{l}\text { 1st core material } \\
\text { Iqro' }\end{array}$ \\
\hline 09.00-09.15 & Break \\
& Washing hands, eating snacks \\
\hline 09.15-10.30 & $\begin{array}{l}\text { 2nd core material } \\
\text { Closing }\end{array}$ \\
\hline
\end{tabular}


Table 2 Diniyah program

\begin{tabular}{|c|c|}
\hline Time & Activities \\
\hline $10.00-11.15$ & $\begin{array}{l}\text { Opening } \\
\text { Eating snacks/fruits }\end{array}$ \\
\hline $11.15-12.00$ & 1st core material (religion) \\
\hline $12.00-13.00$ & $\begin{array}{l}\text { Praying duhur } \\
\text { Lunch } \\
\text { Break }\end{array}$ \\
\hline $13.00-13.30$ & 2nd core material (religion) \\
\hline $13.30-14.30$ & Take a nap \\
\hline $14.30-15.00$ & Closing (bath, asar prayer, snack meal, closing prayers) \\
\hline
\end{tabular}

The following activities of Class $\mathrm{A}$ was at least able to provide an overview of the application of the schedule.

Table 3 Activities in the class

\begin{tabular}{ll} 
Time & \multicolumn{1}{c}{ Activities } \\
\hline 08.00 & The teacher greeted by saying hello, then the children responded in unison. \\
\hline 08.10 & $\begin{array}{l}\text { With the aid of an assistant, the main teacher invited the children together to } \\
\text { read (by memorizing) asmaul husna. This activity also involved ABK. } \\
\text { Fulanah, the only ABK in the class, followed carefully asmaul husna readings } \\
\text { accompanied by her guide. }\end{array}$ \\
\hline 08.30 & $\begin{array}{l}\text { Core Material (Art). On this occasion, the children were asked to color a } \\
\text { single sketch of the noodles on the bowl. Two teachers in the class led the } \\
\text { children to color each sketch with crayons. Every child seems to enjoy } \\
\text { learning. Occasionally some of them ask questions relating to the dye } \\
\text { assignment given by the teacher. Fulanah did not want to miss it. She, with } \\
\text { the guidance of her guide, scrawled her crayons to produce a work. }\end{array}$ \\
\hline 09.00 & $\begin{array}{l}\text { Children who have completed their duties were then allowed to take a break } \\
\text { outside the classroom. While the unfinished children remains cultivated live } \\
\text { in the classroom until the coloring task was completed. }\end{array}$ \\
\hline
\end{tabular}

By looking at the programs, IKTQ does not necessarily oblige all children to follow both. They provide flexibility to the child (in this case the guardian) to choose, whether following both or just one program only. Among 185 children registered in kindergarten, only 50 children chose to follow both programs. ABK themselves participated in one program only, 
the regular program. Technically, the children who follow one program were allowed to go home when the clock was at 10:30. Meanwhile, the remaining 50 children remain in place to continue following the diniyah program (Emiyati, 2011).

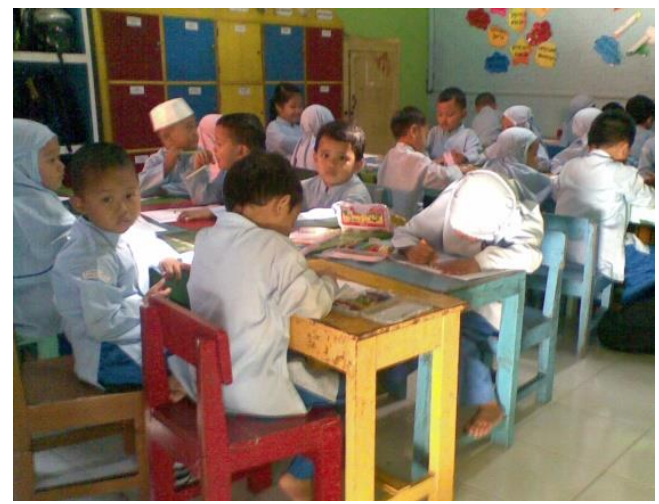

Picture 1 Learning activities in Class A

Basically, the learning activities of IKTQ were almost the same as other kindergarten. This kindergarten is said to be full day because there is diniyah program run until afternoon. Although there are $A B K$ in it, this kindergarten is not totally inclusive. The system and the curriculum used have not fully reflected the inclusion of kindergarten, where the alignments of both aspects have not yet reached 100\%, whereas, the existing system should have a side against the ABK. However, seeing from the will of kindergarten from the beginning willing to accept the presence of $\mathrm{ABK}$, this kindergarten can be called inclusive.

Head of IKTQ also does not realize that the kindergarten she leads inclusive. The word "inclusion" seems to be something new that is essentially familiar. Actually, the beginning of the period of acceptance of 


\section{Mudarrisa: Jurnal Kajian Pendidikan Islam, Vol. 9, No. 2, 2017}

ABK has been ongoing since 2005, and then established a special place of ABK therapy in 2008. Whether labeled by what name, IKTQ just run the mandate to continue to accept children such as $A B K$ because it is a manifestation of humanizing human being (Emiyati, 2011).

Related to the effort above, IKTQ begins with early detection of prospective students, both in terms of health and special needs. In addition to the new student enrollment period, IKTQ also held a kind of identification of child development on the part of academic journey. Learning in IKTQ is organized in a classical way, although sometimes it also takes advantage of individual models. Classical learning is the learning done by the teacher by lecturing in the classroom (Sholihah, 2011). This lesson, as expressed by Sagala, reflects the teacher's primary ability. It includes an efficient model. Teachers here do two activities at once, manage classes and manage learning (Sagala, 2010). With an average of 25 children per class, classical learning is appropriate to use.

In the process of learning in the classroom, teachers do not give special treatment to the crew. In addition to avoiding the envy of non$\mathrm{ABK}$, it also aims not to discriminate between one child and another. Therefore, at a practical level $\mathrm{ABK}$ must follow the learning from beginning to end, from opening, core, to closing. The example of learning processes involving $\mathrm{ABK}$ in the classroom can be seen again in Table 3.

In relation to this, the teacher said, "Kalau dari pihak sini tidak ada (special treatment). Tapi kan kita kalau seumpamanya ada anak ABK yang mau sekolah di sini yang penting ada pendampingnya. Kalau di sini kan kita 


\section{Mudarrisa: Jurnal Kajian Pendidikan Islam, Vol. 9, No. 2, 2017}

sudah pegang anak 25 geh, terus kalau di kelas nambah satu anak itu harus ada pendamping. Pendampingnya itu bisa orang rumah atau gurunya....". Based on this statement, there is no special treatment for $\mathrm{ABK}$ and also non-ABK. In essentials, IKTQ provide an opportunity for the guardians to have their own choice of guide or IKTQ that select the guide for them.

As a note, the process of searching $A B K$ guide here is given to the parent/guardian of the child. However, IKTQ does not necessarily reject when a guardian asks for help to find an appropriate guide for his or her child, especially for parents whose knowledge is minimal in this matter. Then, in an inclusive classroom, the presence of $A B K$ seems to be the center of attention for other children. This is a bit more influential, both for $A B K$ itself and for his friends. The positive effects are the birth of empathy and concern from non-ABK to $A B K$. ABK will also get a lot of stimulus to help his/her social and mental development, while the negative effect is a nuisance of children who are nosy to ABK. Faced with this, teachers often give understanding to all children that there is plurality, diversity, and difference around them.

One of ABKs had told the teacher that she actually enjoyed the conditions when she interacted with other children (non-ABK). Even she had her own terms to distinguish between a special place for ABK with where she mixed with others. The former was called the "Blue School", and she uses the term "Green School" to name the second place (Sholihah, 2011). 
According to the head of IKTQ, there were no special activities that accentuate the skills of $\mathrm{ABK}$ in this kindergarten. Yet if you look at the duration of this kindergarten to receive $A B K$, this kindergarten should also facilitate children with special needs to display their potential, so that the child's development can be seen by the general public. Even so, the shows of $\mathrm{ABK}$ can actually reduce the connotative impression that leads negatively to them. From here, the community will reflect and contemplate when there is an attempt to marginalize ABK outside and not look at them with "one eye".

Further, the development of children in IKTQ was assessed through observations made by the teachers. From the results of these direct observations the teacher then made a separate note about the child. The records were ultimately documented into a progress report of the child's progress that will be communicated to the parents. However, the assessment unfortunately did not touch the two ABKs who joined in learning with other children. The development of $A B K$ was assessed when they were in a special place of ABK therapy, though assessment when socialization with non-ABK children is actually important to do. It is useful to see the comparison of developmental achievements while in each of these places.

Inclusive learning in Islamic Kindergarten Taruna al-Qur'an certainly had a supporting element in the implementation process. The factor that supported the process was the preservation of communication between teachers and guides. For example, for the case of Fulanah, they 


\section{Mudarrisa: Jurnal Kajian Pendidikan Islam, Vol. 9, No. 2, 2017}

often held talks mainly related to motor development. As for the case of Fulan, teachers regularly discussed the development of the spirit of learning. In addition, the child's social development was also not escaped from their supervision.

Another factor that supported the inclusive learning was a good relationship through a meeting that involves all teachers in every week. The meeting was held every Friday. Through the forum each teacher was given the opportunity to complement each other and provide input for the advancement of kindergarten. The implementation of inclusive learning was also supported by communication between IKTQ and parents verbally or through a liaison document, especially related to child development. Then, in conjunction with the constraints, the teacher explicitly explained that they did not face some kind of obstacles related to the inclusiveness of learning in kindergarten. Even if there is an obstacle, it seems that the teachers only considered it as a spice or color for their performance (Sholihah, 2011).

The education implementation described by IKTQ implies that Islamic kindergarten should be inclusive. It refers to what Allah said in Surah 'Abasa, paragraph 1 until 11.

(1) The Prophet frowned and turned away; (2) Because there came to him the blind man, [interrupting]; (3) But what would make you perceive, [O Muhammad], that perhaps he might be purified; (4) Or be reminded and the remembrance would benefit him?; (5) As for he who thinks himself without need; (6) To him you give attention; (7) And not upon you [is any blame] if he will not be purified; (8) But as for he who came to you striving 
[for knowledge]; (9) While he fears [Allah]; (10) From him you are distracted; (11) No! Indeed, these verses are a reminder (Surahs, 2016).

In the paragraphs above, there is a lesson to be learned. Allah gives a warning to Prophet Muhammad not to choose in treating someone. Allah encourages us to be an inclusive person, not exclusive. In the formal education, if an educational unit has an inclination to be inclusive, it can choose to be a totally inclusive or semi inclusive unit. For an emerging education unit, perhaps the appropriate step is to improve the system gradually, not frontally. There are many things that need to be prepared to become a truly inclusive educational unit. Among them are finance, human resources, and infrastructure.

\section{CONCLUSION}

Learning in Islamic Kindergarten Taruna al-Qur'an was represented into regular programs and diniyah programs. In addition to often using the classical learning model, teachers occasionally also took advantage of individual models. Of both programs, kindergarten did not require all children to follow both. Children were free to choose whether to follow all or just one program. From 185 children, only 50 children chose to follow both programs. $\mathrm{ABK}$ only participated in regular programs. Here, $\mathrm{ABK}$ was emphasized in their socialization.

Child development was assessed through observation. From the observation, the teacher then made a separate note about the child. In the final stages, the records were documented into a progress report of the 
child progress that will be communicated to the parents. Assessment had not yet touched the two ABKs who joined in learning with other children. The development of ABK was only assessed when they were in a special place of ABK therapy.

The factors that supported inclusive learning in Islamic Kindergarten Taruna al-Qur'an was the preservation of communication between teachers and guides. Another factor was the existence of a good relationship through a meeting that involved all teachers in every week. It was also supported by communication between IKTQ and parents either verbally or through a liaison document, especially related to child development. While related to obstacles, teachers explicitly reveal that they did not face any kind of barrier to the inclusiveness of learning in kindergarten.

It is then recommended that with regard to its inclusiveness, IKTQ should not wait for the lack of ABK's ability to socialize when the child is really going to be mixed with other children. Otherwise, there is a tendency that the existence of $A B K$ is not totally accepted in non-ABK's class. With regard to the assessment, although the development of ABK had been assessed in the special place of $A B K$, it would be better if when $\mathrm{ABK}$ interacts with other children, the assessment is also maximized.

\section{References}

Arikunto, S. (1991). Metodologi Penelitian kualitatif. Jakarta: Grafindo Persada. 
Emiyati, D. (2011, November 29). Inclusive Education in Islamic Kindergarten. (Agung, Interviewer)

Kountur, R. (2005). Metode Penelitian untuk Penulisan Skripsi dan Tesis. Jakarta: PPM.

NN. (2011, November 11). Inclusive Education in Islamic Kindergarten. (Agung, Interviewer)

Rahman, H. S. (2002). Konsep Dasar Pendidikan Anak Usia Dini. Yogyakarta: PGTKI Press.

Sagala, S. (2010). Konsep dan Makna Pembelajaran: Untuk Membantu Memecahkan Problematika Belajar dan Mengajar. Bandung: Alfabeta.

Sholihah, M. N. (2011, December 6). Inclusive Education in Islamic Kindergarten. (Agung, Interviewer)

Strauss, A., \& Corbin, J. (2003). Dasar-dasar Penelitian Kualitatif. Yogyakarta: Pustaka Pelajar.

Stubbs, S. (2002). Pendidikan Inklusif: Ketika hanya ada sedikit sumber, trans. Susi Septaviana R.

Suakardi. (2002). Metodologi Penelitian Pendidikan: Kompetensi dan Prakteknya. Jakarta: Bumi Aksara.

Sumiyati. (2011). PAUD Inklusi, PAUD Masa Depan. Yogyakarta: Cakrawala Institute.

Surahs. (2016). Retrieved November 29, 2017, from The Noble Qur'an: https://quran.com/80.

Zayadi, A., \& Majid, A. (2005). Tadzkirah Pendidikan Agama Islam (PAI) Berdasarkan Pendekatan Kontekstual. Jakarta: RajaGrafindo Persada. 